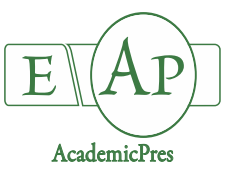

Šaulienè I et al. (2021)

Notulae Botanicae Horti Agrobotanici Cluj-Napoca

Volume 49, Issue 3, Article number 12444

DOI: $10.15835 /$ nbha49312444

Research Article

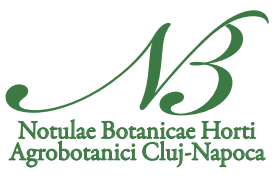

\title{
Automatic particle detectors lead to a new generation in plant diversity investigation
}

\author{
Ingrida ŠAULIENË*, Laura ŠUKIENĖ, Gintautas DAUNYS, \\ Gediminas VALIULIS, Lukas VAITKEVIČIUS
}

\author{
Vilnius University, Siauliai Academy, Institute of Regional Development, P. Višinskis str. 25, 76351, Šiauliai, Lithuania; \\ ingrida.sauliene@sa.vu.It ("'corresponding author); laura.sukiene@sa.vu.lt; gintautas.daunys@sa.vu.lt; gediminas.valiulis@sa.vu.It; \\ lukas.vaitkevicius@sa.vu.It
}

\begin{abstract}
Technological progress in modern scientific development generates opportunities that create new ways to learn more about objects and systems of nature. An important indicator in choosing research methods is not only accuracy but also the time and human resources required to achieve results. This research demonstrates the possibilities of using an automatic particle detector that works based on scattered light pattern and laserinduced fluorescence for plant biodiversity investigation. Airborne pollen data were collected by two different devices, and results were analysed in light of the application for plant biodiversity observation. This paper explained the possibility to gain knowledge with a new type of method that would enable biodiversity monitoring programs to be extended to include information on the diversity of airborne particles of biological origin. It was revealed that plant conservation could be complemented by new tools to test the effectiveness of management plans and optimise mitigation measures to reduce impacts on biodiversity.
\end{abstract}

Keywords: airborne pollen; Hirst type spore trap; near real-time data

\section{Introduction}

Studies on the botanical diversity of plants, particularly the restoration of the floristic richness of a certain territory, are closely related to the pollen data (Reitalu et al., 2019). The use of palynological data significantly contributed to the analysis of the evolution of biodiversity and its dependence on climate (Bellard et al., 2012). Pollen-vegetation relationships investigated on the background of the fossil pollen are not sufficient during the current requirements for scientific knowledge. Schüler et al. (2014) highlight that modern pollen-rain studies are crucial for the calibration and the interpretation of fossil pollen records. The reconstruction and the analysis of past vegetation composition can be enhanced by studying current pollen samples and contemporary vegetation (Felde et al., 2014). In the last decade, the use of airborne pollen data in the analysis of plant ecology (Sharma and Khanduri, 2007), biogeography (Mercuri, 2015) or in studies of phenological phase shift indicators (Veriankaite et al., 2010; Tormo et al., 2011; Cunha et al., 2015; Simón et al., 2018) became more intense. The perspective role of airborne pollen monitoring in providing relevant data for the protection of plants and its potential applications to the management of plant diversity can be very

Received: 06 Jul 2021. Received in revised form: 13 Aug 2021. Accepted: 23 Aug 2021. Published online: 08 Sep 2021.

From Volume 49, Issue 1, 2021, Notulae Botanicae Horti Agrobotanici Cluj-Napoca journal uses article numbers in place of the traditional method of continuous pagination through the volume. The journal will continue to appear quarterly, as before, with four annual numbers. 
relevant and should be taken into account (Fernández-Llamazares et al., 2014). Vegetation mapping was also implemented from the airborne pollen data sets. Based on the airborne pollen data the valuable information and uniquely maps for 12 plant taxa with a high spatial resolution were created for Great Britain (McInnes et al., 2017). Vegetation maps have particular importance when it comes to determining the distribution of invasive plants or assessing the effectiveness of mitigation measures. Reliable examples could be the airborne pollen data used to assess the prevalence of ragweed as an invasive plant (Thibaudon et al., 2014; Skjøth et al., 2019).

Information on changes in plant diversity revealed through airborne pollen dispersion is essential not only for potential applications to the conservation of biodiversity. A large part of the data is used in communication and dissemination about the distribution of allergenic pollen, which is vital for people affected by hay fever or their clinicians. Changes in the habitats of anemophilous plants affect biodiversity and could impact the quality of life of persons susceptible to pollen allergens. The number of people who are sensitive and allergic to pollen is growing for various reasons and the change in biodiversity is one of the most significant ones (Haahtela et al., 2013). People with hay fever can gain treatment (Klimek et al., 2019; Bousquet et al., 2020; Pfaar et al., 2021) and information on adverse pollen effects on health through mobile apps (CAMS, 2019). However, gradually new challenges arise. The positive and significant relationship between springtime rhinovirus infections and airborne birch pollen concentrations revealed in a large Swedish cohort (Gilles et al., 2020). Associations between statistical data of allergenic pollen load and COVID-19 disease showed that without lockdown, an increase of pollen abundance by 100 pollen $/ \mathrm{m}^{3}$ resulted in a $4 \%$ average increase in infection rates (Damialis et al., 2021). The arguments described above reinforce the need for up-to-date information on the diversity of plants, especially the ones producing allergenic pollen.

A multi-faceted need to have information on airborne pollen dispersal has long been met using fieldlaboratory methods. Using these, air samples are collected by traps operating on active suction or particle sedimentation principles. Samples are analysed in the laboratory by identifying particles under a microscope (Galán et al., 2014), recognising DNA (Williams et al., 2001; Kraaijeveld et al., 2015), or performing other measurements (Carvalho et al., 2008; Buters et al., 2012). Recently, a new generation of devices has been developed to evaluate the properties of bioaerosol in near real-time. Devices operating on the principle of image analysis (Oteros et al., 2020), holograms (Sauvageat et al., 2020), or laser-induced fluorescence (Šaulienè et al., 2019) collect digital data on airborne particles. Studies have shown that running automatic detectors collect sufficient information, and anemophilous plant pollen can be identified by neural network-based algorithms (Daunys et al., 2021; Schaefer et al., 2021). Current practices form preconditions for integrating existing experiences into assessing changes and abundance of plant diversity or habitat shift.

This research aims to demonstrate the possibilities of using an automatic particle detector for plant biodiversity investigation and observation.

\section{Materials and Methods}

\section{Sampling area and evaluation of airborne pollen diversity}

Air samples to determine the diversity of pollen were collected in Šiauliai. Šiauliai is the fourth most populated city in Lithuania, in the northern part of the country. About $23 \%$ of the city's territory consists of green areas. The largest parks located near the study area $(\sim 1.2-2 \mathrm{~km})$ are The Central, Talkša and Salduvè. Oaks, birches, lindens, chestnuts, maples, pines, spruces are prevailing in parks.

Airborne pollen was identified by using two different devices during February-April in 2019-2020. Both devices are installed approximately at the height of 20 meters above the ground. The research was performed by using (1) the Hirst type volumetric trap (Hirst, 1952) and (2) an automatic particle detector Rapid-E (Plair $\mathrm{SA})$. Both devices differ in their capabilities as well as their methods of detecting and identifying air samples. 
By using the Hirst type volumetric trap, samples were collected continuously for 7-days per week. All procedures from samples collection, pollen identification and data evaluation were performed by using a conventional method (Galan et al., 2014) and European standard (EN16868,2019). A light microscope and the method of scanning 12 transverse lines was used to identify pollen in air samples. Airborne pollen biodiversity in samples was determined based on the specific morphological characteristics of the pollen by identifying the plant family or genus.

With the automatic particle detector Rapid-E, pollen information was collected analysing the fluorescence and scattering of the particles detected by the device. The device recorded data about airborne particles in size of 5-100 $\mu \mathrm{m}$. An algorithm developed by Šauliene et al. (2019) was used to identify airborne pollen by specifying it in bioaerosol and calculated the total amount of pollen. Woody and herbaceous plants pollen datasets (Valiulis et al., 2020a; Valiulis et al., 2020b) were used to discriminate between pollen and nonpollen particles.

Micrographs were taken using a Nikon digital camera D5000 with an AF-S Micro Nikkor 105mm f / 2.8G IF-ED lens. Pollen was magnified using a light microscope with a $63 \mathrm{x}$ objective.

\section{Statistical data analysis}

Data manipulation, statistical analysis and graphical visualisation were performed using $\mathrm{R}$ ( $\mathrm{R}$ Core Team, 2018) and R Studio (RStudio Team, 2016). In research, we used ggplot2 (Wickham, 2016) viridis (Garnier et al., 2021), lubridate (Grolemund and Wickham, 2011), ggExtra (Attali and Baker 2018) statistical packages. Daily pollen concentrations were normalised using the log normalisation method to compare data collected from different devices. Box and whisker graphs were plotted by calculating the minimum and maximum values, quartiles, and median of daily pollen concentration.

\section{Results}

The daily variation of pollen concentration is shown in Figure 1. With the automatic particle detector, more pollen is usually detected than with the Hirst type volumetric trap. This trend was found in both years of the experiment.

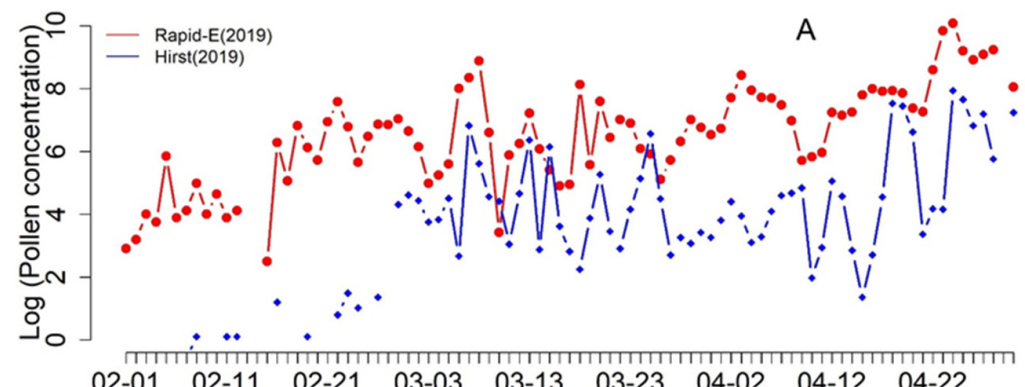

02-01 $02-11 \quad 02-21 \quad 03-03 \quad 03-13 \quad 03-23 \quad 04-02 \quad 04-12 \quad 04-22$

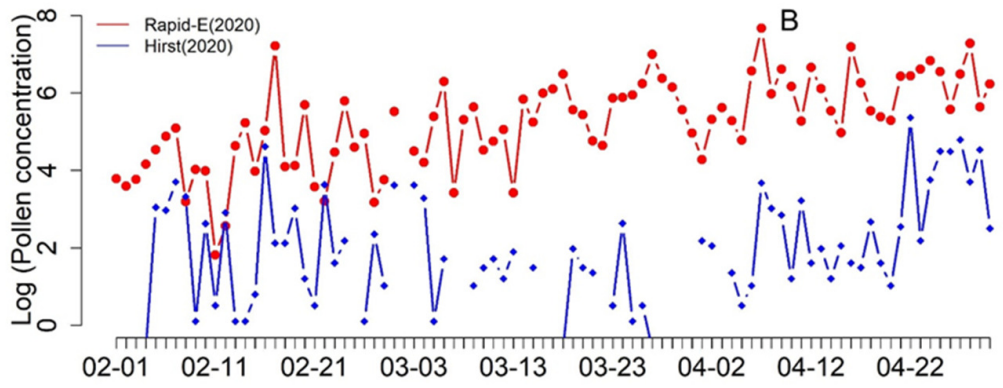

Figure 1. Log (pollen concentration) time series from February 1 to April 30 for A - 2019, B - 2020. Pollen data obtained from the Hirst type volumetric trap and the automatic particle detector Rapid-E 
The data showed that the pollen concentration differs depending on the study years. Evaluating the associations between the data on airborne pollen concentrations collected by two different methods, it was found that the dynamic is similar when higher pollen concentration was recorded by the Hirst-type volumetric method. We prove this statement by the results presented in Figure 1. Higher pollen concentration in March and late April of 2019 is an example. It is also seen similarly in February and late April of 2020.

Pollen concentrations tend to increase with the progress of the vegetation period. In Lithuania, depending on meteorological conditions, early flowering plants (Corylus, Alnus) begin to pollinate at the end of February. The situation is represented as well by the results obtained regarding pollen dispersion in the air (Figure 1 and Figure 2).
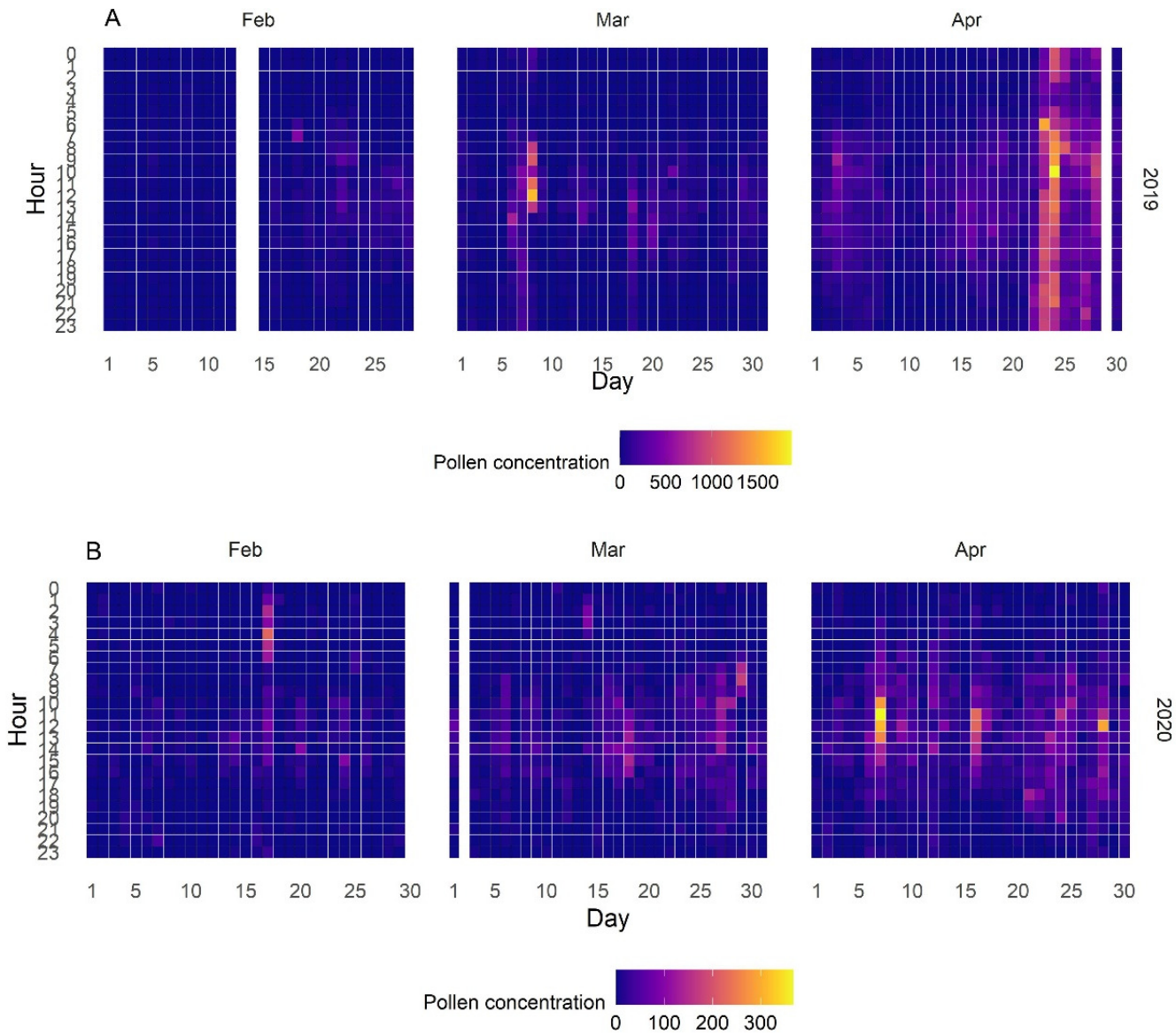

Figure 2. Heatmap of pollen concentration calculated according to near real-time pollen observation data recorded by automatic particle detector Rapid-E

The vertical axis indicates hours and the horizontal - days of month. A - measurements in 2019 and B - measurements in 2020.

Figure 2 demonstrates the tendency in pollen concentration associated with the diurnal cycle. The results show that the main load of the pollen concentration is obtained during daylight hours, i.e. from 9 a.m. until 7 p.m. By analysing the data of the particular months, it should be noted that the trends of the diurnal cycle do not prevail at high pollen concentrations. An obvious example is at the end of April 2019. April 2225 , an exceptionally high pollen concentration was found, calculated from a large number of pollens registered throughout the day. In 2020 the situation is different, as 8 times less pollen was registered than in 2019. 
The data collected with the Hirst type volumetric trap allow estimating the abundance of individual pollen taxa during the analysed period. There are no differences in the diversity of observed pollen of anemophilous plants. During both experiment years, pollen from Alnus, Betula, Corylus, Cupressaceae, Quercus, Salix, Ulmus was identified in the air samples (Figure 3 and Figure 4).

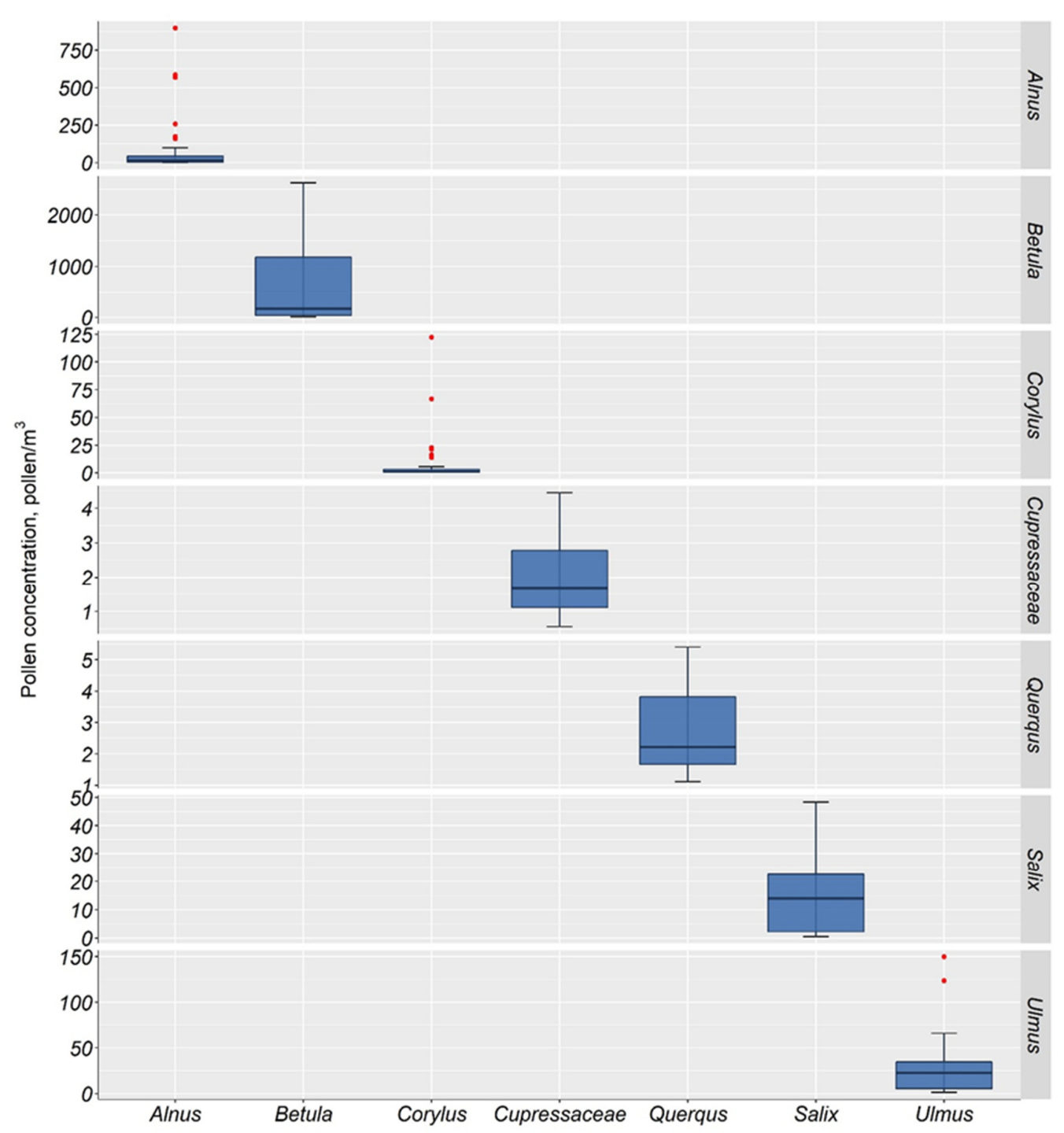

Figure 3. Distribution of pollen concentration according to identified pollen types

Concentration was calculated from data obtained from samples collected with the Hirst type volumetric trap during February 1 and April 30, 2019. Data are presented as Box-Whiskers plots, showing median, 10-90 percentiles and outliers.

Significant differences in pollen abundance were obtained for the identified pollen taxa in 2019 and 2020. Betula pollen was the most abundant during the study period (average 717 pollen $/ \mathrm{m}^{3}$ per day in 2019 and 30 pollen $/ \mathrm{m}^{3}$ in 2020). Less pollen is spread by Alnus (average 61 pollen $/ \mathrm{m}^{3}$ per day in 2019 and 7 pollen $/ \mathrm{m}^{3}$ in 2020) and Corylus ( 7 pollen $/ \mathrm{m}^{3}$ and 4 pollen $/ \mathrm{m}^{3}$ respectively), which usually flowers earlier in Lithuania (classified as the indicators of spring phenological phases) than other taxa of Betulaceae family. Pollen from Salix plants with an entomophilous-anemophilous pollination strategy is identified in small 
amounts in the air samples (average 15 pollen $/ \mathrm{m}^{3}$ in 2019 and 3 pollen $/ \mathrm{m}^{3}$ in 2020). Ulmus pollen, like other pollen types, was significantly less in 2020 than in 2019.

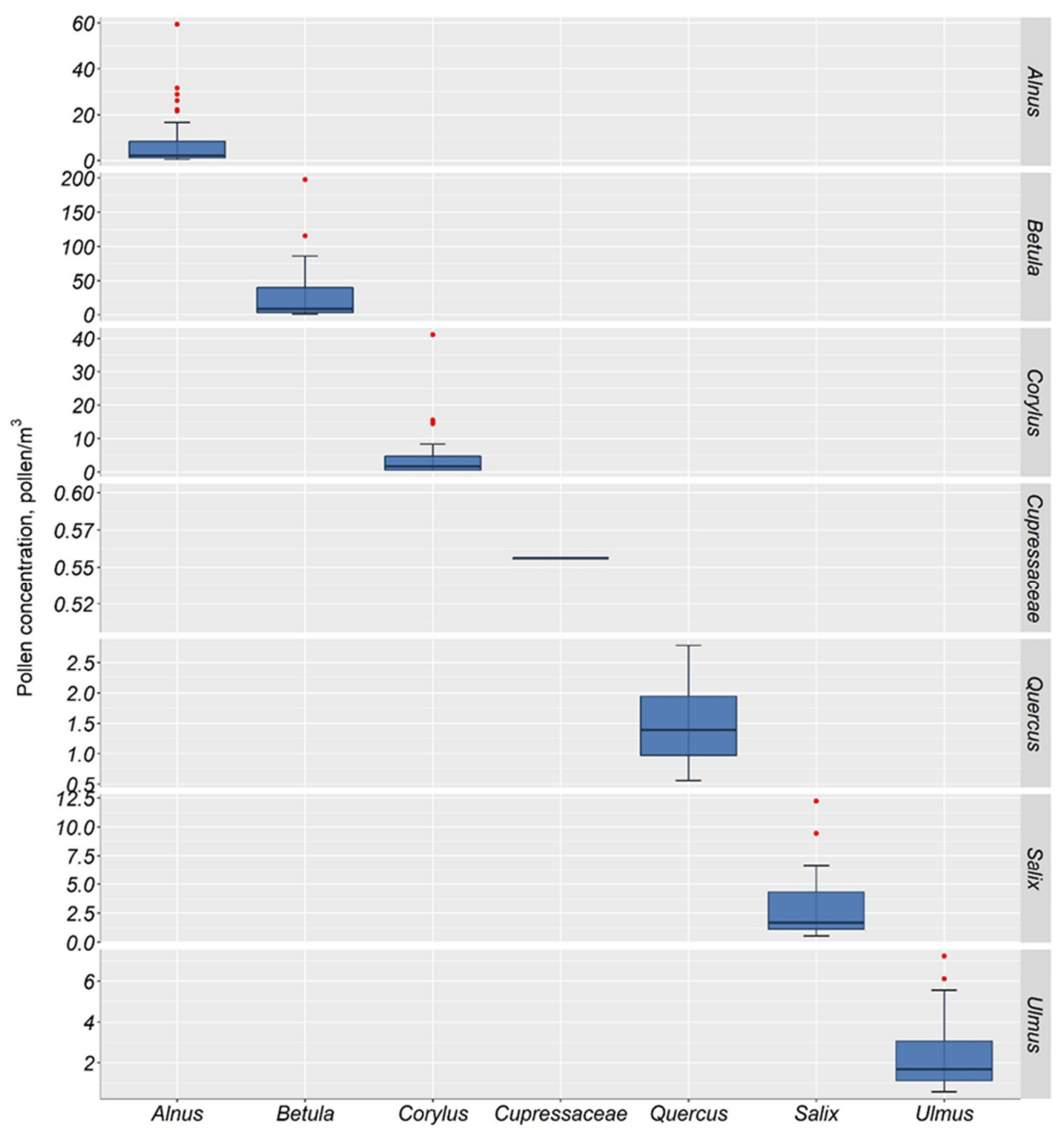

Figure 4. Distribution of pollen concentration according to identified pollen types

Concentration was calculated from data obtained from samples collected with the Hirst type volumetric trap during February 1 and April 30, 2020. Data are presented as Box-Whiskers plots, showing median, 10-90 percentiles and outliers.

Micrographs of pollen detected in air samples and identified are shown in Figure 5. Airborne pollen appears to be well discriminated from other particles in the samples. Pollen differs in morphological characteristics. 


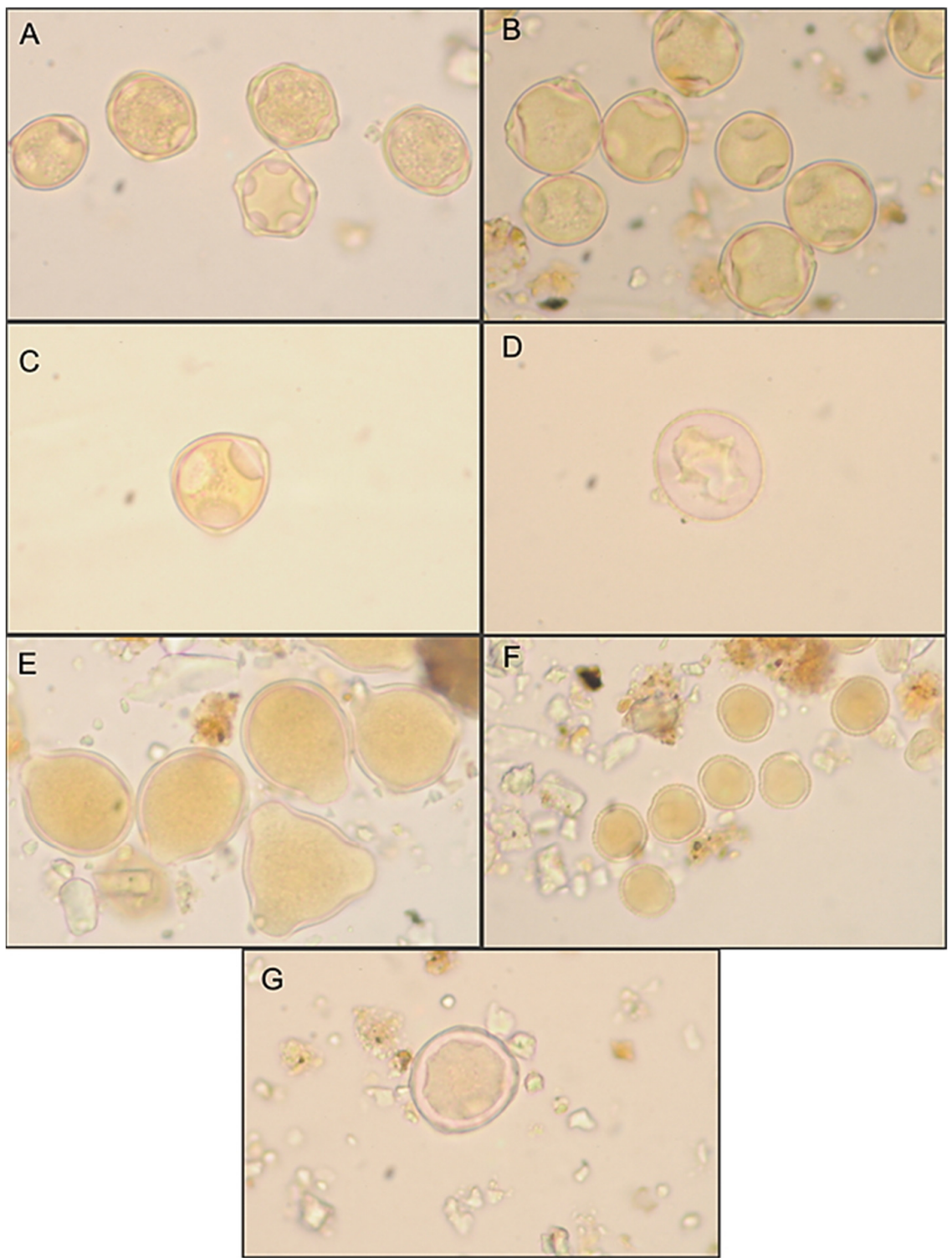

Figure 5. The light micrographs (magnification 63x) of pollen from samples collected with Hirst volumetric trap in 2019

A - Alnus on March 7, B - Betula on April 18, C - Corylus on March 25, D - Cupressaceae on March 25, E - Quercus on April 27, F - Salix on April 25, G- Ulmus on April 9.

Characteristics are the basis for the identification of particles in air samples collected by Hirst type volumetric traps. Pollen of the Betulaceae family is similar in size to each other but differs in the number of apertures or shape. For example, Betula pollen is triporate, as Corylus but different in aperture size. Alnus is distinct from this group with five stephanoporate apertures. Quercus pollen is larger than other identified pollen. The specificity is due to the size differences between lengthwise and polar view diameter. They are characterized by tricolpate apertures. Salix pollen is relatively small, making it reasonably easy to discriminate from other pollen of early spring flowering anemophilous plants. 


\section{Discussion}

In this study, we demonstrated the ability of laser spectroscopy based automatic particle detectors to appear in identification of pollen from airborne biological origin particles (Figure 1 and Figure 2). In this study, we demonstrated the ability of laser spectroscopy-based automatic particle detector to collect the necessary amount of data to discriminate pollen from airborne biological origin particles. Automatic particle detectors can operate year-round without human intervention and provide valuable information on airborne biodiversity. For a long time, this information was only available due to time-consuming work in laboratories where microscopic or chemical analysis methods (Galán et al. 2014; Williams et al., 2001; Kraaijeveld et al., 2015; Carvalho et al., 2008, Buters et al., 2012) were used. To obtain precise results, researchers analysing the development of vegetation (Felde et al., 2014; Reitalu et al., 2019), the mechanisms of genetic information transfer (Sharma and Khanduri, 2007), or studying plant habitats (Mercuri, 2015) had to have sufficient human resources to acquire the necessary knowledge. In the current paper, we revealed the message that pollen data identified in samples collected with a Hirst type volumetric trap could be representatively used to illustrate information collected with an automatic particle detector. In cases when pollen recorded with an automatic detector cannot be classified to genus or species (e.g., in the presence of a large variety of pollen in the air), pollen collected by Hirst type traps are an additional data source. Studies in different countries have shown good results when comparing data collected with automatic detectors and a Hirst type volumetric trap (Šaulienè et al., 2019; Tešendić et al., 2020).

Data collected by automatic particle detectors can provide results that meet a specific need or purpose because plenty of digital data is collected. By applying different identification algorithms, various types of information become available. The Rapid-C device is similar to the device used in our study, but is focused on the detection of viruses, bacteria, and fungi applied to bio-contamination in industrial processes and clean rooms (Huffman et al., 2020). Data collected by Rapid-E were also used to monitor particles of non-biological origin, such as desert dust (Šikoparija, 2020). The information collected by these devices can be valuable for monitoring the biodiversity of natural and urban areas. Monitoring data to analyse aspects of biodiversity change may be periodic, but the increased recreational use of urban or suburban greenery during the isolation of the COVID-19 pandemic requires operational information. In this context, the commitment to identify biological origin particles (especially allergens) becomes vital. Tree pollen emissions can be considered the main source of emissions of coarse particulate matter in urban environments (Cariñanos et al., 2017). The abundance of ragweed in agricultural fields and the evaluation of the effectiveness of control measures are also performed using pollen concentrations (Skjøth et al., 2019). Our data analysis showed that the automatic particle detector well defines pollen abundance (Figure 2). The aforementioned fact makes it possible to suppose the possibility of obtaining similar results for other biological origin allergenic particles.

At the same time, it should be noted that the use of automatic particle detectors in practice is so far more sporadic than a traditional application. The possibilities of these devices are abundantly analysed by the international scientific community (Šaulienè et al., 2019; Šikoparija, 2020; Schaefer et al., 2021). New knowledge is usually sought to obtain operational information for public health purposes (Huffman et al., 2020; Tešendić et al., 2020). Regardless of the evident need for the new generation particles detectors, several limiting factors remain as significant obstacles. There are only a few types of devices on the market, so the price is relatively high compared to spore traps operating on volumetric or sedimentation methods for bioaerosols sampling. A lack of original digital libraries with data that enables precise evaluation of biological origin particles exists. Even pollen diversity is a significant challenge, as particle characteristics are not limited to typical morphology (Figure 5). Specificity is determined by the state of dry and hydrated pollen (PalDat, 2000), indicators of environmental pollution (Anenberg et al., 2020) or plant richness (Reitalu et al., 2019). Specialised digital libraries have started to be developed (Valiulis et al., 2020a; Valiulis et al., 2020b), but the need to continually add new data is high. Assessing the broader demand for more than just pollen recognition, the target of creating libraries of airborne plant pathogens is one of the most important tasks. This would speed 
up data integration and provide access to up-to-date information on the airborne dispersal of crop-damaging agents.

\section{Conclusions}

Automatic particle detectors specialised for identifying pollen in air bioaerosol can be used in plant or its pathogens diversity studies. A new type of knowledge would enable biodiversity monitoring programs to be extended to include information on the diversity of airborne particles of biological origin. Plant conservation could be complemented by new tools to test the effectiveness of management plans and optimise mitigation measures to reduce impacts on biodiversity.

\section{Authors' Contributions}

Conceptualization: IŠ, ĽS, GD, GV, LV; Data curation: IŠ, GD, GV, LV; Visualization: L.Š; Project administration: IŠ; Writing - original draft: IŠ and LŠ; Writing - review and editing: IŠ, LŠ, GD, GV, LV.

All authors read and approved the final manuscript.

\section{Acknowledgements}

This research has been supported by the European Social Fund (project no. 09.3.3-LMT-K-712-010066) under grant agreement with the Research Council of Lithuania (LMTLT).

\section{Conflict of Interests}

The authors declare that there are no conflicts of interest related to this article.

\section{References}

Anenberg SC, Haines S, Wang E, Nassikas N, Kinney PL (2020). Synergistic health effects of air pollution, temperature, and pollen exposure: a systematic review of epidemiological evidence. Environmental Health 19:1-19. https://doi.org/10.1186/s12940-020-00681-Z

Attali D, Baker C (2018). ggExtra: Add Marginal Histograms to 'ggplot2', and More 'ggplot2' Enhancements. R package version 0.8. Retrieved 2021 July 07 from https://cran.r-project.org/web/packages/ggExtra/index.html

Bellard C, Bertelsmeier C, Leadley P, Thuiller W, Courchamp F (2012). Impacts of climate change on the future of biodiversity. Ecology Letters 15:365-377. https://doi.org/10.1111/j.1461-0248.2011.01736.x

Bousquet J, Akdis CA, Jutel M, Bachert C, Klimek L, Agache I, ... Philip L (2020). Intranasal corticosteroids in allergic rhinitis in COVID-19 infected patients: An ARIA-EAACI statement. Allergy 75:2440-2444. https://doi.org/10.1111/all.14302

Buters JT, Thibaudon M, Smith M, Kennedy R, Rantio-Lehtimäki A, Albertini R, ... Hialine Working Group (2012). Release of Bet $\mathrm{v} 1$ from birch pollen from 5 European countries. Results from the HIALINE study. Atmospheric Environment 55:496-505. https://doi.org/10.1016/j.atmosenv.2012.01.054

Cariñanos P, Calaza-Martínez P, O’Brien L, Calfapietra C (2017). The cost of greening: disservices of urban trees. In: Pearlmutter D, Calfapietra C, Samson R, O’Brien L, Ostoić SK, Sanesi G, Alonso del Amo R (Eds). The Urban Forest. Springer, Cham pp 79-87. 
Carvalho E, Sindt C, Verdier A, Galan C, O’Donoghue L, Parks S, Thibaudon M (2008). Performance of the Coriolis air sampler, a high-volume aerosol-collection system for quantification of airborne spores and pollen grains. Aerobiologia 24:191-201. https://doi.org/10.1007/s10453-008-9098-y

Copernicus Atmosphere Monitoring Service (CAMS) (2019) Pioneering personalised allergy medicine Retrieved 2021 July 1 from https://atmosphere.copernicus.eu/pioneering-personalised-allergy-medicine

Cunha M, Ribeiro H, Costa P, Abreu I (2015). A comparative study of vineyard phenology and pollen metrics extracted from airborne pollen time series. Aerobiologia 31:45-56. https://doi.org/10.1007/s10453-014-9345-3

Damialis A, Gilles S, Sofiev M, Sofieva V, Kolek F, Bayr D, ... Covid-19/Pollen Study Group (2021). Higher airborne pollen concentrations correlated with increased SARS-CoV-2 infection rates, as evidenced from 31 countries across the globe. Proceedings of the National Academy of Sciences 118(12). https://doi.org/10.1073/pnas.2019034118

Daunys G, Šukienė L, Vaitkevičius L, Valiulis G, Sofiev M, Šaulienè I (2021). Clustering approach for the analysis of the fluorescent bioaerosol collected by an automatic detector. PloS One 16:e0247284. https://doi.org/10.1371/journal.pone.0247284

EN16868 (2019). Ambient air-Sampling and analysis of airborne pollen grains and fungal spores for networks related to allergy - Volumetric Hirst method. European Standards.

Felde VA, Peglar SM, Bjune AE, Grytnes JA, Birks HJB (2014). The relationship between vegetation composition, vegetation zones and modern pollen assemblages in Setesdal, southern Norway. The Holocene 24:985-1001. https://doi.org/10.1177/0959683614534745

Fernández-Llamazares Á, Belmonte J, Boada M, Fraixedas S (2014). Airborne pollen records and their potential applications to the conservation of biodiversity. Aerobiologia 30:111-122. https://doi.org/10.1007/s10453013-9320-4

Galán C, Smith M, Thibaudon M, Frenguelli G, Oteros J, Gehrig R, ... EAS QC Working Group (2014). Pollen monitoring: minimum requirements and reproducibility of analysis. Aerobiologia 30:385-395. https://doi.org/10.1007/s10453-014-9335-5

Garnier S, Ross N, Rudis R, Filipovic-Pierucci A, Galili T, timelyportfolio, ... Chen JJ (2021). sjmgarnier/viridis: viridis 0.6.0 (pre-CRAN release) (Version v0.6.0pre). Zenodo. http://doi.org/10.5281/zenodo.4679424

Gilles S, Blume C, Wimmer M, Damialis A, Meulenbroek L, Gökkaya M, ... Traidl-Hoffmann C (2020). Pollen exposure weakens innate defense against respiratory viruses. Allergy 75:576-587. https://doi.org/10.1111/all.14047

Grolemund G, Wickham H (2011). Dates and times made easy with lubridate. Journal of Statistical Software 40:1-25. https://doi.org/10.18637/jss.v040.103

Haahtela T, Holgate S, Pawankar R, Akdis CA, Benjaponpitak S, Caraballo L, ... von Hertzen L (2013). The biodiversity hypothesis and allergic disease: world allergy organization position statement. World Allergy Organization Journal 6:1-18. https://doi.org/10.1186/1939-4551-6-3

Hirst J (1952). An automatic volumetric spore trap. Annals of Applied Biology 39:257-265. https://doi.org/10.1111/j.1744-7348.1952.tb00904.X

Huffman JA, Perring AE, Savage NJ, Clot B, Crouzy B, Tummon F, ... Pan Y (2020). Real-time sensing of bioaerosols: Review and current perspectives. Aerosol Science and Technology 54:465-495. https://doi.org/10.1080/02786826.2019.1664724

Klimek L, Bachert C, Pfaar O, Becker S, Bieber T, Brehler R. ... Bousquet J (2019). ARIA guideline 2019: treatment of allergic rhinitis in the German health system. Allergo Journal International 28:255-276. https://doi.org/10.1007/s40629-019-00110-9

Kraaijeveld K, De Weger LA, Ventayol García M, Buermans H, Frank J, Hiemstra PS, Den Dunnen JT (2015). Efficient and sensitive identification and quantification of airborne pollen using next-generation DNA sequencing. Molecular Ecology Resources 15:8-16. https://doi.org/10.1111/1755-0998.12288

McInnes RN, Hemming D, Burgess P, Lyndsay D, Osborne NJ, Skjøth CA, ... Vardoulakis S (2017). Mapping allergenic pollen vegetation in UK to study environmental exposure and human health. Science of the Total Environment 599:483-499. https://doi.org/10.1016/j.scitotenv.2017.04.136

Mercuri AM (2015) Applied palynology as a trans-disciplinary science: the contribution of aerobiology data to forensic and palaeoenvironmental issues. Aerobiologia 31:323-339. https://doi.org/10.1007/s10453-015-9367-5

Oteros J, Weber A, Kutzora S, Rojo J, Heinze S, Herr C, ... Buters JT (2020). An operational robotic pollen monitoring network based on automatic image recognition. Environmental Research 191:110031. https://doi.org/10.1016/j.envres.2020.110031 
PalDat (2000). PalDat - a palynological database. Retrieved 2021 July 5 from https://www.paldat.org/

Pfaar O, Agache I, Bergmann KC, Bindslev-Jensen C, Bousquet J, Creticos PS, ... Frew AJ (2021). Placebo effects in allergen immunotherapy-an EAACI Task Force Position Paper. Allergy 76:629-647. https://doi.org/10.1111/all.14331

R Core Team (2018). R: A Language and Environment for Statistical Computing. R Foundation for Statistical Computing. Retrieved 2021 June 28 from https://www.R-project.org/

RStudio Team (2016). R Studio: Integrated Development for R. R Studio. Retrieved 2021 June 28 from http://www.rstudio.com/

Reitalu T, Bjune AE, Blaus A, Giesecke T, Helm A, Matthias I, ... Birks HJB (2019). Patterns of modern pollen and plant richness across northern Europe. Journal of Ecology 107:1662-1677. https://doi.org/10.1111/13652745.13134

Šaulienė I, Šukienė L, Daunys G, Valiulis G, Vaitkevičius L, Matavulj P, ... Sofiev M (2019). Automatic pollen recognition with the Rapid-E particle counter: the first-level procedure, experience and next steps. Atmospheric Measurement Techniques 12:3435-3452. https://doi.org/10.5194/amt-12-3435-2019

Sauvageat E, Zeder Y, Auderset K, Calpini B, Clot B, Crouzy B, ... Vasilatou K (2020). Real-time pollen monitoring using digital holography. Atmospheric Measurement Techniques 13:1539-1550. https://doi.org/10.5194/amt-131539-2020

Schaefer J, Milling M, Schuller B., Bauer B., Brunner JO, Traidl-Hoffmann C, Damialis A (2021). Towards automatic airborne pollen monitoring: From commercial devices to operational by mitigating class-imbalance in a deep learning approach. Science of The Total Environment 148932. https://doi.org/10.1016/j.scitotenv.2021.148932

Schüler L, Hemp A, Behling H (2014). Relationship between vegetation and modern pollen-rain along an elevational gradient on Kilimanjaro, Tanzania. The Holocene 24:702-713. https://doi.org/10.1177/0959683614526939

Sharma CM, Khanduri VP (2007). Pollen-mediated gene flow in Himalayan long needle pine (Pinus roxburghii Sargent). Aerobiologia 23:153-158. https://doi.org/10.1007/s10453-007-9056-0

Šikoparija B (2020). Desert dust has a notable impact on aerobiological measurements in Europe. Aeolian Research 47:100636. https://doi.org/10.1016/j.aeolia.2020.100636

Simón BE, Latorre F, Rotundo C (2018). Study of the reproductive phenology of Araucaria angustifolia in two environments of Argentina: Its application to the management of a species at risk. Global Ecology and Conservation 16:e00483. https://doi.org/10.1016/j.gecco.2018.e00483

Skjøth CA, Sun Y, Karrer G, Sikoparija B, Smith M, Schaffner U, Müller-Schärer H (2019). Predicting abundances of invasive ragweed across Europe using a “top-down” approach. Science of the Total Environment 686:212-222. https://doi.org/10.1016/j.scitotenv.2019.05.215

Tešendić D, Boberić Krstićev D, Matavulj P, Brdar S, Panić M, Minić V, Šikoparija B (2020). RealForAll: real-time system for automatic detection of airborne pollen. Enterprise Information Systems 1-17. https://doi.org/10.1080/17517575.2020.1793391

Thibaudon M, Šikoparija B, Oliver G, Smith M, Skjøth CA (2014). Ragweed pollen source inventory for France-The second largest centre of Ambrosia in Europe. Atmospheric Environment 83:62-71. https://doi.org/10.1016/j.atmosenv.2013.10.057

Tormo R, Silva I, Gonzalo Á, Moreno A, Pérez R, Fernández S (2011). Phenological records as a complement to aerobiological data. International Journal of Biometeorology 55:51-65. https://doi.org/10.1007/s00484-0100308-2

Valiulis G, Šukienė L, Vaitkevičius L, Daunys G, Sofiev M, Šaulienė I (2020a). Woody plants pollen dataset from automatic particle detector in Šiauliai (Version 1.1.0) [Data set]. Zenodo. http://doi.org/10.5281/zenodo.3873205

Valiulis G, Šukienė L, Vaitkevičius L, Daunys G, Sofiev M, Šaulienė I (2020b). Herbaceous plants pollen dataset from automatic particle detector in Šiauliai (Version 1.1.0) [Data set]. Zenodo. http://doi.org/10.5281/zenodo.3873204

Veriankaite L, Šaulienè I, Bukantis A (2010). The modelling of climate change influence on plant flowering shift in Lithuania. Žemdirbystè (Agriculture) 97:41-48.

Wickham H (2016). ggplot2: Elegant Graphics for Data Analysis. Springer-Verlag New York. 
Williams RH, Ward E, McCartney HA (2001). Methods for integrated air sampling and DNA analysis for detection of airborne fungal spores. Applied and Environmental Microbiology 67:2453-2459. http://doi.org/10.1128/AEM.67.6.2453-2459.2001

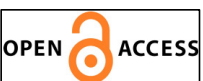

(c) (1)

The journal offers free, immediate, and unrestricted access to peer-reviewed research and scholarly work. Users are allowed to read, download, copy, distribute, print, search, or link to the full texts of the articles, or use them for any other lawful purpose, without asking prior permission from the publisher or the author.

License - Articles published in Notulae Botanicae Horti Agrobotanici Cluj-Napoca are Open-Access, distributed under the terms and conditions of the Creative Commons Attribution (CC BY 4.0) License.

(c) Articles by the authors; UASVM, Cluj-Napoca, Romania. The journal allows the author(s) to hold the copyright/to retain publishing rights without restriction. 